\title{
Development and psychometric evaluation of performance-based upper extremity motor control test (PB-UE-MCT) for people with cerebral palsy
}

\author{
Desenvolvimento e avaliação psicométrica do Teste de Controle Motor \\ das Extremidades Superiores com Base no Desempenho (PB-UE-MCT) \\ para pessoas com paralisia cerebral
}

Fatemeh Etemad Shams ${ }^{a}$ (D), Malek Amini ${ }^{a}$ (D), Afsoon Hassani Mehraban ${ }^{a}$ (D), Mehdi Alizadeh Zarei ${ }^{\mathrm{a}}$ (D), Dorsa Kalani ${ }^{\mathrm{b}}$ (D)

${ }^{a}$ Department of Occupational Therapy, School of Rehabilitation Sciences, Iran University of Medical Sciences,

Tehran, Iran.

${ }^{\text {b}}$ Department of Kinesiology, University of Waterloo, Waterloo, Ontario, Canada.

How to cite: Shams, F. E., Amini, M., Mehraban, A. H., Zarei, M. A., \& Kalani, D. (2021).

Development and psychometric evaluation of performance-based upper extremity motor control test (PB-UE-MCT) for people with cerebral palsy. Cadernos Brasileiros de Terapia Ocupacional, 29, e2853. https://doi.org/10.1590/2526-8910.ctoAO21567

\begin{abstract}
$\underline{\text { Abstract }}$
Introduction: Upper extremity disorders limits the performance in the activities of daily living, especially, in bilateral (two-handed) activities. Objective: This study was designed to develop a performance-based upper extremity motor control test (PB-UE-MCT) and to measure its psychometric properties (including, convergent validity, intrarater reliability, and interrater reliability) for people with cerebral palsy (CP). Method: The PB-UE-MCT was developed in three phases, including planning, construction, and psychometric evaluation. The participants included 50 people with $\mathrm{CP}$ with an age range of 6 to 18 years. To measure internal consistency, Cronbach's alpha was run $(\mathrm{n}=50)$. Intrarater and interrater reliability was measured for 25 participants. To assess convergent validity, the correlations of the PB-UE-MCT with the Manual Ability Classification System (MACS) and with the Selective Control Upper Extremity Scale (SCUES) were calculated. Results: The values obtained for Cronbach's alpha (.90 to .96) indicated the excellent internal consistency of the PB-UE-MCT. The ICC values for intrarater reliability and interrater reliability were between .84 and .99 and between .89 and .99 , respectively. The correlation coefficients obtained for the items of the PB-UEMCT and those of the MACS were between .51 and .73. The correlation coefficients of the items of the PB-UE-MCT with those of the SCUES were in the
\end{abstract}

Received on Sept. 16, 2020; Accepted on Feb. 9, 2021.

This is an Open Access article distributed under the terms of the Creative Commons Attribution License, which permits unrestricted use, distribution, and reproduction in any medium, provided the original work is properly cited. 
range of .67 to .98 , which proves the PB-UE-MCT's good to excellent levels of convergent validity. Conclusion: The results confirm that the PB-UE-MCT is a valid and reliable tool for evaluating the upper extremity performance of people with CP through task analysis.

Keywords: Cerebral Palsy, Upper Extremity, Professional Practice, Activities of Daily Living.

\section{$\underline{\text { Resumo }}$}

Introdução: Distúrbios dos membros superiores limitam o desempenho nas atividades da vida diária, especialmente em atividades bilaterais (com as duas mãos). Objetivo: Desenvolver um teste de controle motor de membros superiores baseado em desempenho (PB-UE-MCT) para avaliar pessoas com paralisia cerebral espástica. Método: O PB-UE-MCT inclui planejamento, construção e avaliação psicométrica. Os participantes incluíram 50 pessoas com paralisia cerebral entre 6 e 18 anos. Para medir a consistência interna, o alfa de Cronbach foi executado $(n=50)$. A confiabilidade intra-examinador foi medida para 25 participantes que realizaram o teste duas vezes com um intervalo de duas semanas. Para confiabilidade entre avaliadores, dois examinadores administraram separadamente o teste a 25 participantes. Para avaliar a validade convergente, foram calculadas as correlaçóes do PB-UE-MCT com o Manual Ability Classification System (MACS) e com a Selective Control Upper Extremity Scale (SCUES). Resultados: Os valores obtidos para o alfa de Cronbach $(0,90$ a 0,96$)$ indicaram a excelente consistência interna do PB-UE-MCT. Os valores de ICC para confiabilidade intraexaminador e confiabilidade interexaminador estavam entre 0,84 e 0,99 e entre 0,89 e 0,99 , respectivamente. Os coeficientes de correlaçáo obtidos para os itens do PB-UEMCT e do MACS ficaram entre 0,51 e 0,73. Os coeficientes de correlação dos itens do PB-UE-MCT com os das SCUES situaram-se na faixa de 0,67 a 0,98, o que comprova os níveis de validade convergente bons a excelentes do PB-UE-MCT. Conclusão: O PB-UE-MCT é uma ferramenta válida e confiável para avaliar o desempenho dos membros superiores de pessoas com paralisia cerebral durante a realização de tarefas.

Palavras-chave: Paralisia Cerebral, Extremidade Superior, Prática Profissional, Atividades Diárias.

\section{Introduction}

Numerous activities of daily living require the proper function of the upper extremity. Upper extremity performance involves fine and gross motor skills that are impaired in almost all people with cerebral palsy (CP). The most prominent disorder related to muscle tone and strength occurs in the muscles of the distal part of the upper extremity, which limits the performance of these people in the activities of daily living, especially, in bilateral (two-handed) activities that account for $76 \%$ of the activities (Klingels et al., 2012; Pashmdarfard \& Shervin Badv, 2019). In 2010, Bridenwick et al. concluded that the loss of active supination restricted $74 \%$ of the activities of daily living, and due to the motor control impairments of many people with cerebral palsy, 
active supination cannot function properly (Braendvik et al., 2010). Currently, there is a consensus of opinion among scientific and academic scholars all over the world on using a top-down approach and making interventions purposeful and occupation-based. However, one of the drawbacks to the rehabilitation of people with CP is that a majority of interventions in occupational therapy focus on the improvement of motor components, such as muscle tone and range of motion (Anaby et al., 2017), while improving motor components may not enhance the occupational performance in some people.

Therefore, one possible way to develop top-down interventions is to use assessment tools that evaluate motor components through the activities of daily living in a topdown manner and to estimate changes in motor components via assessing the daily life performance of these people. The above mentioned points have been rarely addressed in the previous studies. For example, there are some tools, such as the Selective Control of Upper Extremity Scale (SCUES) and the Quality of Upper Extremity Skills Test(QUEST), that accurately and precisely analyze both upper extremity at the joint level and fine motor skills; nonetheless, they merely evaluate motor components and are not performance-based. To put it in other terms, they only assess motor components and overlook everyday occupations (Demetteo \& Law, 1993; Wagner et al., 2016). Probably, in such conditions, it is more effective to use the instruments that analyze and evaluate motor performance through the activities of daily living; consequently, the current study aimed to construct the Performance-based Upper Extremity Motor Control Test (PB-UE-MCT) for people with cerebral palsy and measure its psychometric properties.

\section{Method}

In the present study, the methodological approach with the aim of developing an instrument was used. The development of the instrument was done in three phases as follows:

\section{Phase 1: Planning}

Step 1: Clarifying the purpose of the study and describing the target group: This study was designed to construct the performance-based upper extremity motor control tool for 6- to 8-year-old people with spastic cerebral palsy with an IQ score over 70 and no vision problems.

Step 2: Reviewing the existing literature and instruments and detecting parents' priorities regarding upper extremity activities: In this step, first, an initial review of the previous studies on the upper extremity performance of people with cerebral palsy was done to find out whether there was any valid, reliable, and appropriate assessment tool for performance-based upper extremity motor control. The review of these studies reveals that no study has been undertaken to assess performance-based upper extremity motor control and the available tools merely evaluate motor components. In the next step, the studies conducted on the upper extremity performance and upper extremity motor control of people with cerebral palsy were checked and the priorities of these people and their families concerning upper extremity activities of daily living were 
scrutinized. Then, based on this literature review, two activities that include fine and gross motor skills, involve all the movements at the joints of the upper extremity, and were among the activities of daily living were selected. These two activities were drinking from a glass and drawing a line (connecting two points with a line).

\section{Phase 2: Construction}

Step 3: Forming a panel of experts to appraise the selected activities and decide on the scoring process: In this step, a panel of specialists consisting of 7 occupational therapists with at least 5 years of clinical experience was formed. In this panel, there were one professor (with a Ph.D. degree), two assistant professors (with a Ph.D. degree), and four occupational therapy Ph.D. students. The purpose of this panel was to evaluate and verify the selected activities, analyze movements in the selected activities, and decide on how to score the developed test items. These two activities along with the joint motions in each component of these two activities were analyzed. The following issues are settled by this panel of experts:

1 - It is required to provide a comprehensive manual for the test implementation. The standard and proper conditions for performing the test should be introduced by the examiner. So, the examiner should precisely provide the purpose and the overall image of the test, correct positioning, the standards of the tools and equipment used, the way each item is scored (in case of independent performance, performance with others' help, and inability to perform each step), and the exclusion criteria;

2- The whole tasks and part tasks are assessed for the right and left hands separately with the score range of 0 to 2 . Those performing each step properly and independently achieve score 2 . Those completing a step incompletely or with the assistance of the examiner obtain score 1 , and those unable to do a step are given 0 . Figure 1.

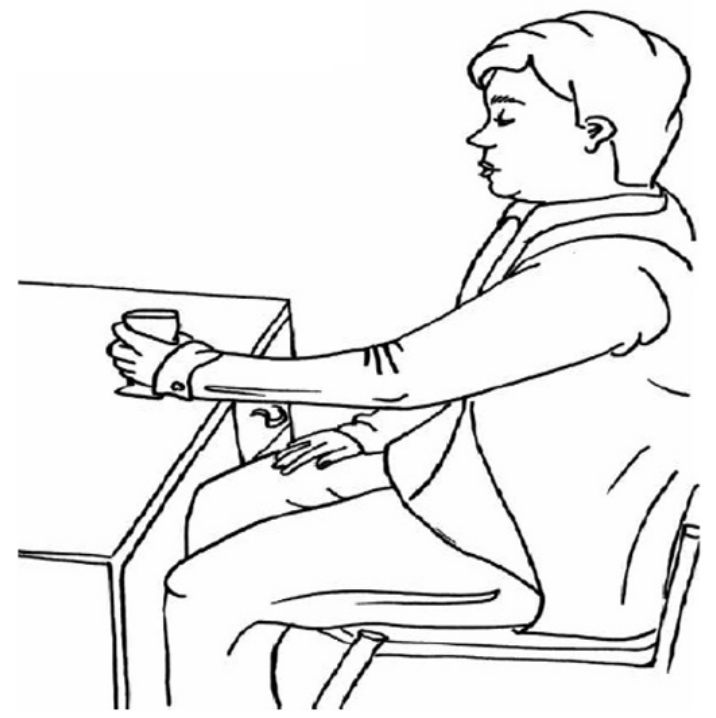

Figure 1. Reach for the glass on the table. 
3- The correct and standard positioning of the person performing the test activities is described and the standard equipment is used to perform the two activities of the test. This information is explained in detail in the test instruction;

4- The performance of each joint is scored only once during the activity;

5- One of the phases of performing the activity of drinking from a glass) i.e., opening the hand) is combined with the phase of reaching for the glass on the table;

6- In the writing phase of the activity of drawing a line, the line is drawn from right to left to analyze the movement of shoulder adduction;

7- The target group is determined. Considering the chosen activities and the normal growth pattern, 6- to 18-year-old people with cerebral palsy are selected as the target group of this study;

8- The inclusion criteria are determined based on the selected activities and the review of the previous studies (Jalili et al., 2019). These criteria are as follows: having an IQ score above 70, not being blind, not having any severe vision problems.

Step 4: Formulating the test instruction: Considering the experts' emphasis on the need to provide comprehensive instruction (manual) for implementing the test, the test instruction was prepared and formulated based on the opinions and suggestions of the experts and the review of the existing literature on this issue. The test instruction includes the following items:

- The standard and proper conditions needed for the test administration;

- The correct positioning for performing each activity;

- The standards of the used tools and equipment.

- The precise information on how to score each item (in case of independent performance, performance with others' help, and inability to implement each step), which was determined by the panel of experts.

Step 5: Evaluating the content and face validity of the test: the face and content validity was done in the panel of experts in the form of discussion and review of one by one items and due to the nature of the test, quantitative methods such as lavshe were not used.

\section{Phase 3: Psychometric Evaluation}

\section{Participants}

The inclusion criteria were as follows: being 6- to 18- years old, having spastic cerebral palsy, and obtaining an IQ score above 70. To measure internal consistency, intrarater reliability, and interrater reliability, the sample sizes were 50, 25, and 25 patients with cerebral palsy, respectively.

\section{Data collection procedure}

After the selection of the samples based on the inclusion criteria, 50 participants with spastic cerebral palsy (38 females and 12 men) who were in the age range of 6 to 18 
years and had no vision problems participated in this study (their demographic characteristics, type of cerebral palsy, and frequency are presented in Table 1). Initially, the written consent was obtained and the necessary explanations about the purpose of the research were given to them, and then, the participants were evaluated. The assessment steps were as follows: 1) the demographic questionnaire was completed by the examiner with the help of the persons with cerebral palsy or their family, 2) the Manual Activity Classification System (MACS) was completed by their family, 3) the SCUES was performed for both right and left hands by the first examiner, and finally, 4) the PB-UE-MCT was done for the patients by the first examiner.

Table 1. Demographic characteristics of participants.

\begin{tabular}{|c|c|c|c|}
\hline & & frequency & Percent \% \\
\hline \multirow{2}{*}{ gender } & female & 38 & 76 \\
\hline & male & 12 & 24 \\
\hline \multirow{4}{*}{$\mathrm{CP}^{*}$ type } & Hemiplegia & 13 & 26 \\
\hline & Diplegia & 25 & 50 \\
\hline & quadriplegia & 10 & 20 \\
\hline & Monoplegia & 2 & 4 \\
\hline \multirow{2}{*}{ Assistive device } & Yes & 3 & 94 \\
\hline & No & 47 & 6 \\
\hline \multirow{4}{*}{ GMFCS $^{* *}$} & Level 1 & 9 & 18 \\
\hline & Level 2 & 29 & 58 \\
\hline & Level 3 & 6 & 12 \\
\hline & Level 4 & 6 & 12 \\
\hline \multirow{5}{*}{ MACS $^{* * *}$} & Level 1 & 23 & 46 \\
\hline & Level 2 & 9 & 18 \\
\hline & Level 3 & 10 & 20 \\
\hline & Level 4 & 3 & 6 \\
\hline & Level 5 & 5 & 10 \\
\hline
\end{tabular}

${ }^{*}$ Cerebral Palsy. ${ }^{* *}$ Gross Motor Function Classification System. ${ }^{* * *}$ Manual Ability Classification System.

\section{Reliability}

To assure the internal consistency of the PB-UE-MCT, 50 patients with cerebral palsy were assessed. Cronbach's alpha coefficient was used to calculate the internal consistency of the test (Terwee et al., 2007). To measure intrarater reliability, the first examiner administered the PB-UE-MCT to 25 participants twice with an interval of two weeks. To estimate interrater reliability, 25 participants were evaluated by the first examiner and 25 patients by the second examiner) an Occupational Therapist). To be more precise, initially, the first examiner administered the test, and after 10 minutes, the second examiner took the test. Each examiner scored the patients' performance separately. 


\section{Convergent validity}

To measure convergent validity, the correlations of the PB-UE-MCT with the SCUES (is a tool to assess the movements of the upper extremity joint by joint) and with the MACS were calculated. The correlations were separately computed for each overall activity (drinking from a glass and drawing a line) and for each whole task in the activities. These correlations were estimated for the right and left hands separately.

\section{Measures}

\section{Demographic questionnaire}

This questionnaire includes items related to age, gender, type of cerebral palsy, level of upper extremity ability based on the MACS, the presence or absence of vision problems, the severity of vision problems, and the need for upper extremity assistive devices.

\section{Manual Ability Classification System (MACS)}

The MACS is a classification system to measure the manual ability of children with cerebral palsy. It categorizes the ability of these children to perform the activities of daily living into five levels, with level 1 representing the highest functional level and level 5 the lowest functional level. The values of test-retest reliability obtained for the parents and therapists were ICC $=0.967$ and ICC $=0.974$, respectively (Riyahi et al., 2013).

\section{Selective Control Upper Extremity Scale (SCUES)}

The SCUES is a tool used for the evaluation of voluntary motor control of upper extremity. In this tool, the abduction and adduction of shoulders, the flexion and extension of elbows, the pronation and supination of forearms, the flexion and extension of wrists, and grasping and releasing fingers are scored from 0 (the absence of voluntary control) to 3 (the normal mode). The interrater reliability values were reported to be very high for the parts related to shoulder, elbow, and forearm movements (ICC $=0.72$ for shoulder movements, ICC $=0.75$ for elbow movements, ICC $=0.76$ for forearm movements) (Wagner et al., 2016).

\section{Performance-based Upper Extremity Motor Control Test (PB-UE-MCT)}

This instrument is comprised of two overall activities (drinking from a glass and drawing a line). Each of these two activities includes several whole tasks, and each whole task consists of some part tasks assessing movements at the joint level. To be exact, the overall activity of drinking from a glass has 6 whole tasks as follows: 1) reaching for the glass on the table, 2) grasping the glass, 3) lifting the glass, 4) tilting the glass to drink, 5) replacing the glass, and 6) releasing the glass. Each of these whole tasks also includes some part tasks (Appendix 1). 
The overall activity of drawing a line has three whole tasks: 1) reaching for the paper on the table, 2) gripping the pen or pencil, 3) connecting two points from right to left. Each of these whole tasks comprises some part tasks.

The whole tasks and their part tasks are separately evaluated for each hand. The scoring range is from 0 to 2 . If a patient performs each task properly and independently, she/he is given a score of 2 . If a patient completes a task incompletely or with the help of the examiner, she/he gets a score of 1 , and if a patient cannot do it, she/he are given a score of 0 . Consequently, a higher score indicates better and more complete performance (the exact scoring procedure and the conditions and standards of implementing the test are provided in the test instruction). If a patient performs all the movements in the activity of drinking from a glass correctly and independently, his/her total score for each hand in the whole-task and part-task sections would be 12 and 48, respectively. Similarly, if a patient completes all the movements in the activity of drawing a line correctly and independently, his/her total score in the whole task and part-task sections would be 6 and 30, respectively.

Table 2. Internal consistency of PB-UE-MCT $(\mathrm{n}=50)$.

\begin{tabular}{|c|c|c|c|}
\hline performance & Whole task & Hand & Cronbach's Alpha \\
\hline \multirow{12}{*}{$\begin{array}{c}\text { Drinking from glass } \\
\text { on the table }\end{array}$} & \multirow{2}{*}{ Reach for the glass on the table } & Right & .96 \\
\hline & & Left & .94 \\
\hline & \multirow{2}{*}{ Grasp the glass } & Right & .95 \\
\hline & & Left & .96 \\
\hline & \multirow{2}{*}{ Lift the glass } & Right & .94 \\
\hline & & Left & .96 \\
\hline & \multirow{2}{*}{ Tilt the glass to drink } & Right & .94 \\
\hline & & Left & .91 \\
\hline & \multirow{2}{*}{ Replace the glass } & Right & .96 \\
\hline & & Left & .96 \\
\hline & \multirow{2}{*}{ Release the glass } & Right & .95 \\
\hline & & left & .92 \\
\hline \multirow{6}{*}{ Drawing one line } & \multirow{2}{*}{ Reach for the paper on the table } & Right & .96 \\
\hline & & Left & .95 \\
\hline & \multirow{2}{*}{ Grip the pen/pencil(dynamic tripod) } & Right & .95 \\
\hline & & Left & .95 \\
\hline & \multirow{2}{*}{ Connect two point (right to left) } & Right & .96 \\
\hline & & left & .90 \\
\hline
\end{tabular}

\section{Statistical analysis}

To carry out the statistical analysis, SPSS software (version 22) was used. To estimate internal consistency, Cronbach's alpha was calculated (Terwee et al., 2007). The intraclass correlation (ICC) was run to measure the interrater and intrarater reliability of the PBUE-MCT (Terwee et al., 2007). Furthermore, to compute the convergent validity of the PB-UE-MCT, its correlations with the MACS and with the SCUES were gauged through the Pearson and Spearman correlation tests, respectively (Terwee et al., 2007). 


\section{Results}

In the present study, the average age of the participants was 12.24 with a standard deviation of 2.51 (maximum age: 18 , minimum age: 7 ).

\section{Reliability}

Internal consistency: The Cronbach's alpha values obtained for all the whole tasks in each activity for the right and left hands were between .90 and .96, which is indicative of excellent internal consistency (Terwee et al., 2007) (Table 2).

Intrarater reliability: The ICC values for 25 participants in the whole tasks and part tasks in both activities for both hands were from .84 to .99 , which reflects very good to excellent intrarater reliability (Terwee et al., 2007) (Table 3).

Interrater reliability: The ICC values for 25 participants in the whole tasks and part tasks of each activity for each hand ranged from .89 to .99 , which shows very good to excellent intrarater reliability (Terwee et al., 2007) (Table 3).

Table 3. interrater and intrarater reliability of PB-UE-MCT $(n=25)$.

\begin{tabular}{|c|c|c|c|c|c|}
\hline performance & Whole task & $\mathbf{N}^{*}$ & Hand & $\begin{array}{l}\text { Intra rater } \\
\text { reliability: } \\
\text { (ICC)(sig) }\end{array}$ & $\begin{array}{l}\text { Interrater } \\
\text { reliability: } \\
\text { (ICC)(sig) }\end{array}$ \\
\hline \multirow{24}{*}{$\begin{array}{l}\text { Drinking } \\
\text { from glass on } \\
\text { the table }\end{array}$} & \multirow{2}{*}{$\begin{array}{l}\text { Reach for the glass on the } \\
\text { table (whole task) }\end{array}$} & 25 & right & $.90(.00)$ & $.97(.00)$ \\
\hline & & 25 & left & $.97(.00)$ & $.98(.00)$ \\
\hline & \multirow{2}{*}{$\begin{array}{c}\text { Reach for the glass on the } \\
\text { table (part task) }\end{array}$} & 25 & Right & $.96(.00)$ & $.96(.00)$ \\
\hline & & 25 & left & $.97(.00)$ & $.97(.00)$ \\
\hline & \multirow{2}{*}{ Grasp the glass(whole task) } & 25 & Right & $.95(.00)$ & $.90(.00)$ \\
\hline & & 25 & left & $.98(.00)$ & $.98(.00)$ \\
\hline & \multirow{2}{*}{ Grasp the glass(part task) } & 25 & Right & $.97(.00)$ & $.95(.00)$ \\
\hline & & 25 & left & $.98(.00)$ & $.98(.00)$ \\
\hline & \multirow{2}{*}{ Lift the glass(whole task) } & 25 & Right & $.97(.00)$ & $.89(.00)$ \\
\hline & & 25 & left & $.97(.00)$ & $.97(.00)$ \\
\hline & \multirow{2}{*}{ Lift the glass-part task) } & 25 & Right & $.99(.00)$ & $.99(.00)$ \\
\hline & & 25 & left & $.99(.00)$ & $.99(.00)$ \\
\hline & \multirow{2}{*}{$\begin{array}{l}\text { Tilt the glass to drink } \\
\text { (whole task) }\end{array}$} & 25 & Right & $.97(.00)$ & $.98(.00)$ \\
\hline & & 25 & left & $.97(.00)$ & $.98(.00)$ \\
\hline & \multirow{2}{*}{$\begin{array}{l}\text { Tilt the glass to drink } \\
\text { (part task) }\end{array}$} & 25 & Right & $.98(.00)$ & $.98(.00)$ \\
\hline & & 25 & left & $.97(.00)$ & $.96(.00)$ \\
\hline & \multirow{2}{*}{ Replace the glass (whole task) } & 25 & Right & $.97(.00)$ & $.90(.00)$ \\
\hline & & 25 & left & $.88(.00)$ & $.97(.00)$ \\
\hline & \multirow{2}{*}{ Replace the glass (part task) } & 25 & Right & $.99(.00)$ & $.97(.00)$ \\
\hline & & 25 & left & $.92(.00)$ & $.98(.00)$ \\
\hline & \multirow{2}{*}{ Release the glass(whole task) } & 25 & Right & $.97(.00)$ & $.98(.00)$ \\
\hline & & 25 & left & $.98(.00)$ & $.98(.00)$ \\
\hline & \multirow{2}{*}{ Release the glass(part task) } & 25 & Right & $.97(.00)$ & $.94(.00)$ \\
\hline & & 25 & left & $.95(.00)$ & $.97(.00)$ \\
\hline \multirow{3}{*}{$\begin{array}{l}\text { Drawing one } \\
\text { line }\end{array}$} & \multirow{3}{*}{$\begin{array}{l}\text { Reach for the paper on the } \\
\text { table(whole task) }\end{array}$} & 25 & Right & $.94(.00)$ & $.93(.00)$ \\
\hline & & 25 & left & $.97(.00)$ & $.97(.00)$ \\
\hline & & 25 & Right & $.99(.00)$ & $.93(.00)$ \\
\hline
\end{tabular}


Table 3. Continued...

\begin{tabular}{|c|c|c|c|c|c|}
\hline performance & Whole task & $\mathbf{N}^{*}$ & Hand & $\begin{array}{l}\text { Intra rater } \\
\text { reliability: } \\
\text { (ICC)(sig) }\end{array}$ & $\begin{array}{l}\text { Interrater } \\
\text { reliability: } \\
\text { (ICC)(sig) }\end{array}$ \\
\hline & $\begin{array}{l}\text { Reach for the paper on the } \\
\text { table(part task) }\end{array}$ & 25 & left & $.96(.00)$ & $.96(.00)$ \\
\hline & \multirow{2}{*}{$\begin{array}{l}\text { Grip the pen/pencil dynamic } \\
\text { tripod)(whole task) }\end{array}$} & 25 & Right & $.97(.00)$ & $.96(.00)$ \\
\hline & & 25 & left & $.84(.00)$ & $.93(.00)$ \\
\hline & \multirow{2}{*}{$\begin{array}{l}\text { Grip the pen/pencil dynamic } \\
\text { tripod)(part task) }\end{array}$} & 25 & Right & $.99(.00)$ & $.97(.00)$ \\
\hline & & 25 & left & $.96(.00)$ & $.97(.00)$ \\
\hline & \multirow{2}{*}{$\begin{array}{c}\text { Connect two point- right to } \\
\text { left(whole task) }\end{array}$} & 25 & Right & $.97(.00)$ & $.96(.00)$ \\
\hline & & 25 & left & $.93(.00)$ & $.91(.00)$ \\
\hline & \multirow{2}{*}{$\begin{array}{c}\text { Connect two point- right to } \\
\text { left(part task) }\end{array}$} & 25 & Right & $.97(.00)$ & $.96(.00)$ \\
\hline & & 25 & left & $.96(.00)$ & $.93(.00)$ \\
\hline
\end{tabular}

${ }^{*} \mathrm{~N}$ : Number of participants

\section{Convergent validity}

The correlation coefficients between the SCUES and the whole tasks of the PB-UEMCT revealed good to excellent convergent validity, and the correlation coefficients between the MACS and the whole tasks of the PB-UE-MCT indicated good convergent validity (Terwee et al., 2007) (Table 4).

Table 4. Convergent validity of PB-UE-MCT with MACS and SCUES.

\begin{tabular}{|c|c|c|c|c|c|}
\hline \multirow{3}{*}{ performance } & \multirow{3}{*}{ Whole task } & \multirow{3}{*}{ Hand } & \multirow{2}{*}{\multicolumn{2}{|c|}{$\begin{array}{c}\begin{array}{c}\text { Pearson correlation } \\
(\text { sig })\end{array} \\
\text { SCUES }\end{array}$}} & \multirow{3}{*}{$\begin{array}{c}\begin{array}{c}\text { Spearman } \\
\text { correlation }(\mathrm{sig})\end{array} \\
\text { MACS }\end{array}$} \\
\hline & & & & & \\
\hline & & & Right & Left & \\
\hline \multirow{12}{*}{$\begin{array}{l}\text { Drinking from } \\
\text { glass on the table }\end{array}$} & \multirow{2}{*}{ Reach for glass on the table } & Right & $.97(.00)$ & - & $-.73(.00)$ \\
\hline & & Left & - & $.86(.00)$ & $-.68(.00)$ \\
\hline & \multirow{2}{*}{ Grasp the glass } & Right & $.85(.00)$ & - & $-.73(.00)$ \\
\hline & & Left & - & $.76(.00)$ & $-.60(.00)$ \\
\hline & \multirow{2}{*}{ Lift the glass } & Right & $.95(.00)$ & - & $-.73(.00)$ \\
\hline & & Left & - & $.90(.00)$ & $-.63(.00)$ \\
\hline & \multirow{2}{*}{ Tilt the glass to drink } & Right & $.89(.00)$ & - & $-.70(.00)$ \\
\hline & & Left & - & $.84(.00)$ & $-.56(.00)$ \\
\hline & \multirow{2}{*}{ Replace the glass } & Right & $.97(.00)$ & - & $-.61(.00)$ \\
\hline & & Left & - & $.92(.00)$ & $-.56(.00)$ \\
\hline & \multirow{2}{*}{ Release the glass } & Right & $.95(.00)$ & - & $-.65(.00)$ \\
\hline & & Left & - & $.78(.00)$ & $-.53(.00)$ \\
\hline \multirow{6}{*}{ Drawing one line } & \multirow{2}{*}{$\begin{array}{l}\text { Reach for the paper on the } \\
\text { table }\end{array}$} & Right & $.94(.00)$ & - & $-.61(.00)$ \\
\hline & & Left & - & $.89(.00)$ & $-.64(.00)$ \\
\hline & \multirow{2}{*}{$\begin{array}{l}\text { Grip the } \\
\text { pen/pencil(dynamic tripod) }\end{array}$} & Right & $.88(.00)$ & - & $-.65(.00)$ \\
\hline & & Left & - & $.75(.00)$ & $-.62(.00)$ \\
\hline & \multirow{2}{*}{$\begin{array}{l}\text { Connect two point } \\
\text { (right to left) }\end{array}$} & Right & $.88(.00)$ & - & $-.56(.00)$ \\
\hline & & Left & - & $.67(.00)$ & $-.51(.00)$ \\
\hline
\end{tabular}


Table 4. Continued...

\begin{tabular}{|c|c|c|c|c|c|}
\hline \multirow{3}{*}{ performance } & \multirow{3}{*}{ Whole task } & \multirow{3}{*}{ Hand } & \multirow{2}{*}{\multicolumn{2}{|c|}{$\begin{array}{c}\begin{array}{c}\text { Pearson correlation } \\
(\mathrm{sig})\end{array} \\
\text { SCUES }\end{array}$}} & \multirow{3}{*}{$\frac{\begin{array}{c}\text { Spearman } \\
\text { correlation }(\text { sig) }\end{array}}{\text { MACS }}$} \\
\hline & & & & & \\
\hline & & & Right & Left & \\
\hline \multirow{4}{*}{$\begin{array}{l}\text { Total } \\
\text { performance }\end{array}$} & \multirow{2}{*}{$\begin{array}{l}\text { Drink from glass on the } \\
\text { table }\end{array}$} & Right & $.98(.00)$ & - & $-.73(.00)$ \\
\hline & & left & - & $.91(.00)$ & $-.64(.00)$ \\
\hline & \multirow{2}{*}{ Drawing one line } & Right & $.94(.00)$ & - & $-.64(.00)$ \\
\hline & & Left & - & $.85(.00)$ & $-.65(.00)$ \\
\hline
\end{tabular}

\section{Discussion}

This study was designed to develop a tool for assessing performance-based upper extremity motion control (PB-UE-MCT) of 6- to 18-year-old people with cerebral palsy. The PB-UE-MCT evaluates all movements of the upper extremity joints through two activities, i.e., drinking from a glass and drawing a line, both of which are part of a person's everyday occupations. These two activities were selected based on the occupational performance priorities of these people according to their parents (Jalili et al., 2019).

One of the most significant advantages of the PB-UE-MCT is its top-down evaluation. Through top-down evaluation, occupational therapists are able to provide more purposeful interventions via assessing the part tasks of the activities of daily living and to observe the positive impacts of these interventions on patients objectively and practically. Currently, the attitude globally prevailing among the scientific and academic scholars is using the top-down approach and making interventions purposeful; however, one of the drawbacks of the rehabilitation of people with cerebral palsy is that most occupational therapy interventions lay emphasis on improving motor components, such as muscle tone and range of motion (Anaby et al., 2017) while improvement in motor components in the many people may not promote one's performance in real-life activities in some cases. As a result, using tools like the PB-UE-MCT that evaluates the performance of motor components in a top-down manner through daily-life activities seems to be helpful in designing more purposeful interventions.

Another advantage of the PB-UE-MCT is its wide-ranging application for all groups of cerebral palsy and for all people with cerebral palsy aged 6 to 18 years. Although the CHEQ (Children's Hand-use Experience Questionnaire) evaluates hand function through one's everyday occupations, it is limited to one group of cerebral palsy, i.e., patients with hemiplegic cerebral palsy, and is not suitable for other groups (Amer et al., 2016). Owing to measuring both whole tasks and movements at the joint level, the PBUE-MCT precisely analyzes the activity of the person and reveals which part of the movement has motor deficiencies during the performance. The information provided via this test can be a good guide for treating these people; in fact, the turning point of the PB-UE-MCT is the precise and meticulous analysis of two activities of daily living, i.e., drinking from a glass and drawing a line. Although the CHEQ examines manual ability through everyday occupations, such careful analysis is not carried out in this instrument (Amer et al., 2016). The ABILHAND-KIDs has similar features to the CHEQ in this regard. Although the ABILHAND-KIDs measures children's manual ability to perform the activities of daily living, it does not perform any detailed analysis 
of movements in each activity. In this tool, if a person does not get a complete score, it is not exactly clear where the problem lies and with which movement or joint the person has problems; therefore, the treatment process is hindered (Arnould et al., 2004).

There are some other tools, such as the SCUES and the QUEST, that accurately and precisely analyze both upper extremity at the joint level and fine motor skills; nonetheless, they merely evaluate motor components and are not performance-based. To put it in other terms, they only assess motor components and overlook everyday occupations (Demetteo et al., 1993). The PB-UE-MCT carefully evaluates both everyday occupations and their part tasks at the joint level. Therefore, it can be concluded that the PB-UE-MCT has a client-centered design, is a comprehensive tool (i.e., it can be used for all groups of cerebral palsy), evaluates people in a top-down manner, and provides the accurate and precise analysis of the activities of daily living. The information provided via this tool makes it possible to identify the main sources of motor disabilities that limit the occupational performance of people with cerebral palsy and to develop proper treatment plans for these people accordingly. Hence, this tool is very useful for and very effective in evaluating and treating people with cerebral palsy.

The reliability of the PB-UE-MCT is at an acceptable level. Regarding the intrarater reliability, all the scores were .90 or above, which indicates the high temporal consistency of this tool. It means that if the evaluation is repeated after a short interval (for example, two weeks), similar results would be obtained, and the time gap does not have any considerable impact on the evaluation. However, concerning the SCUES, the intrarater reliability values are estimated to be .6 and .75 in shoulder movements and elbow movements, respectively (Wagner et al., 2016). In the CHEQ, the score range of reliability is .87 to .91 (Amer et al., 2016). In the MACS, the intrarater reliability is measured with an interval of four weeks and the values are between .80 and .90 (Riyahi et al., 2013; Joveini et al., 2020). Comparing the results of the abovementioned studies with those obtained in this study shows that the PB-UE-MCT has the best temporal consistency.

Concerning the interrater reliability, the achieved values were .89 or above, which indicates the very low impact of examiners on the participants' activity performance. The interrater reliability of the SCUES is .72 for shoulder movements and .76 for elbow movements (Wagner et al., 2016). Regarding the MACS, the range of the interrater reliability values is .87 to .90 (Riyahi et al., 2013). The comparison of the results of these studies with those of the current study reveals that the interrater reliability of the PB-UE-MCT is at a satisfactory level and converges with the tools used in other studies.

The results also show a range of .90 to .99 for the internal consistency of the PBUE-MCT, confirming the high consistency and coherence of the items in this tool; in other words, all the items in the PB-UE-MCT assess the same concept.

Furthermore, the PB-UE-MCT has acceptable validity as the convergent validity scores between the PB-UE-MCT and the SCUES and between the PB-UE-MCT and the MACS were at an acceptable level, which proves the good correlation of the PB-UEMCT with these two tools.

In sampling phase of present study the pandemic situation of covid-19 caused twomonth stop in the sampling process and limited sample size for inter-rater and intrarater reliability. 


\section{Suggestions for future research}

1- Assessing the validity and correlation of PB-UE-MCT with kinematic motion analysis tools;

2- Assessing the validity and reliability of PB-UE-MCT for adults with neurological disability such as stroke, multiple sclerosis;

3- Assessing the validity and reliability of PB-UE-MCT in other physically disabilities in 6 to 18 years old such as muscular dystrophy.

\section{Conclusion}

The results of the present study confirmed that the validity and reliability of the PBUE-MCT are acceptable; therefore, it can be employed as a practical clinical test with a top-down approach by occupational therapists for assessing and therapy of people with cerebral palsy.

\section{Acknowledgements}

This study was supported by Iran University of Medical Sciences (ethical code: IR.IUMS.REC.1398.882).

\section{References}

Amer, A., Eliasson, A. C., Peny-Dahlstrand, M., \& Hermansson, L. (2016). Validity and test retest reliability of Children's Hand-use Experience Questionnaire in children with unilateral cerebral palsy. Developmental Medicine and Child Neurology, 58(7), 743-749.

http://dx.doi.org/10.1111/dmcn.12991.

Anaby, D., Korner-Bitensky, N., Steven, E., Tremblay, S., Snider, L., Avery, L., \& Law, M. (2017). Current Rehabilitation Practices for Children with Cerebral Palsy: focus and Gaps. Physical \& Occupational Therapy in Pediatrics, 37(1), 1-15. http://dx.doi.org/10.3109/01942638.2015.1126880.

Arnould, C., Penta, M., Renders, A., \& Thonnard, J. L. (2004). ABILHAND-Kids: a measure of manual ability in children with cerebral palsy. Neurology, 63(6), 1045-1052. http://dx.doi.org/10.1212/01.wnl.0000138423.77640.37.

Braendvik, S. M., Elvrum, A. K., Vereijken, B., \& Roeleveld, K. (2010). Relationship between neuromuscular body functions and upper extremity activity in children with cerebral palsy. Developmental Medicine and Child Neurology, 52(2), e29-e34. http://dx.doi.org/10.1111/j.14698749.2009.03490.x.

Demetteo, C., \& Law, M. (1993). The reliability and validity of the quality upper extremity skills test. Physical \& Occupational Therapy in Pediatrics, 13(2), 1-18. http://dx.doi.org/10.1080/J006v13n02_01.

Jalili, N., Nasr, Z., Zare, R., \& Sattari, M. (2019). Occupational performance priorities of children with cerebral palsy from the parents' perspective. Journal of Rehabilitation, 19(4), 370-379. http://dx.doi.org/10.32598/rj.19.4.370.

Joveini, G., Zareiyan, A., Khalafbeigi, M., \& Lajevardi, L. (2020). The comparative content review of the persian participation assessment measures: a systematic review. Iranian Rehabilitation Journal, 18(1), 1-16. http://dx.doi.org/10.32598/ irj.18.1.928.1. 
Klingels, K., Demeyere, I., Jaspers, E., De Cock, P., Molenaers, G., Boyd, R., \& Feys, H. (2012). Upper limb impairments and their impact on activity measures in children with unilateral cerebral palsy. European Journal of Paediatric Neurology, 16(5), 475-484. http://dx.doi.org/10.1016/j.ejpn.2011.12.008.

Pashmdarfard, M., \& Shervin Badv, R. (2019). The impact of manual ability level on participation of children with cerebral palsy in life areas: a cross-sectional study. Iranian Journal of Child Neurology, 13(3), 83-91.

Riyahi, A., Rassafiani, M., Akbarfahimi, N., \& Karimloo, M. (2013). Test-retest and interrater reliabilities of the of Manual Ability Classification System (MACS)-Farsi version in children with cerebral palsy. Journal of Research in Rehabilitation Sciences, 1(1), 203-211. http://dx.doi.org/10.22122/jrrs.v8i2.422.

Terwee, C. B., Bot, S. D., de Boer, M. R., van der Windt, D. A., Knol, D. L., Dekker, J., Bouter, L. M., $\&$ de Vet, H. C. (2007). Quality criteria were proposed for measurement properties of health status questionnaires. Journal of Clinical Epidemiology, 60(1), 34-42. http://dx.doi.org/10.1016/j.jclinepi.2006.03.012.

Wagner, L. V., Davids, J. R., \& Hardin, J. W. (2016). Selective Control of the Upper Extremity Scale: validation of a clinical assessment tool for children with hemiplegic cerebral palsy. Developmental Medicine and Child Neurology, 58(6), 612-617. http://dx.doi.org/10.1111/dmcn.12949.

\section{Author's Contributions}

Fatemeh Etemad Shams, Malek Amini, Afsoon Hassani Mehraban and Mehdi Alizadeh Zarei: project design and supervise, data analysis, final approval of the version to be published and interpreting and discussing results. Fatemeh Etemad Shams and Dorsa Kalani: data collection and wrote the paper. All authors approved the final version of the text.

\section{Corresponding author}

Malek Amini

e-mail: malekamini8@gmail.com; amini.m@iums.ac.ir

\section{Section editor}

Profa. Dra. Ana Alegretti 
Appendix 1. Performance-based Upper Extremity Motor Control Test (PBUE-MCT).

\begin{tabular}{|c|c|c|c|c|c|c|c|}
\hline \multirow[b]{2}{*}{ Performance } & \multirow[b]{2}{*}{ Whole task } & \multicolumn{2}{|c|}{ Scoring $0 / 1 / 2$} & \multirow[b]{2}{*}{ Part task } & \multicolumn{2}{|c|}{ Scoring $0 / 1 / 2$} & \multirow[b]{2}{*}{ Comments } \\
\hline & & $\begin{array}{c}\text { Dominant } \\
\text { Hand }\end{array}$ & $\begin{array}{c}\text { Non } \\
\text { Dominant } \\
\text { Hand }\end{array}$ & & $\begin{array}{c}\text { Dominant } \\
\text { Hand }\end{array}$ & $\begin{array}{c}\text { Non } \\
\text { Dominant } \\
\text { Hand } \\
\end{array}$ & \\
\hline \multirow{19}{*}{$\begin{array}{l}\text { Drinking } \\
\text { from a glass }\end{array}$} & \multirow{6}{*}{$\begin{array}{l}\text { Reach for the } \\
\text { glass on the } \\
\text { table }\end{array}$} & & & $\begin{array}{l}\text { Shoulder } \\
\text { flexion }\end{array}$ & & & \\
\hline & & & & $\begin{array}{c}\text { Elbow } \\
\text { extension }\end{array}$ & & & \\
\hline & & & & $\begin{array}{l}\text { Forearm } \\
\text { midposition }\end{array}$ & & & \\
\hline & & & & $\begin{array}{c}\text { Wrist } \\
\text { extension }\end{array}$ & & & \\
\hline & & & & $\begin{array}{c}\mathrm{MP}^{1} \\
\text { extension }\end{array}$ & & & \\
\hline & & & & $\begin{array}{l}\text { Fingers } \\
\text { extension }\end{array}$ & & & \\
\hline & \multirow{2}{*}{$\begin{array}{l}\text { Grasp the } \\
\text { glass }\end{array}$} & & & MP flexion & & & \\
\hline & & & & $\begin{array}{l}\text { Fingers } \\
\text { flexion }\end{array}$ & & & \\
\hline & \multirow{8}{*}{ Lift the glass } & & & $\begin{array}{l}\text { Shoulder } \\
\text { extension }\end{array}$ & & & \\
\hline & & & & $\begin{array}{l}\text { Shoulder } \\
\text { abduction }\end{array}$ & & & \\
\hline & & & & $\begin{array}{l}\text { Shoulder } \\
\text { Ext. rot }\end{array}$ & & & \\
\hline & & & & $\begin{array}{l}\text { Elbow } \\
\text { flexion }\end{array}$ & & & \\
\hline & & & & $\begin{array}{l}\text { Forearm } \\
\text { midposition }\end{array}$ & & & \\
\hline & & & & $\begin{array}{c}\text { Wrist } \\
\text { extension }\end{array}$ & & & \\
\hline & & & & MP flexion & & & \\
\hline & & & & $\begin{array}{l}\text { Fingers } \\
\text { flexion }\end{array}$ & & & \\
\hline & \multirow{2}{*}{$\begin{array}{l}\text { Tilt the glass } \\
\text { to drink }\end{array}$} & & & $\begin{array}{l}\text { Forearm } \\
\text { pronation }\end{array}$ & & & \\
\hline & & & & $\begin{array}{c}\text { Wrist } \\
\text { radial. } \\
\text { Deviation }\end{array}$ & & & \\
\hline & $\begin{array}{l}\text { Replace the } \\
\text { glass }\end{array}$ & & & $\begin{array}{l}\text { Shoulder } \\
\text { flexion }\end{array}$ & & & \\
\hline
\end{tabular}




\begin{tabular}{|c|c|c|c|c|c|c|c|}
\hline \multirow{7}{*}{ Performance } & \multirow{5}{*}{ Whole task } & \multicolumn{2}{|c|}{ Scoring $0 / 1 / 2$} & \multirow[b]{2}{*}{ Part task } & \multicolumn{2}{|c|}{ Scoring $0 / 1 / 2$} & \multirow[b]{2}{*}{ Comments } \\
\hline & & $\begin{array}{c}\text { Dominant } \\
\text { Hand }\end{array}$ & $\begin{array}{c}\text { Non } \\
\text { Dominant } \\
\text { Hand }\end{array}$ & & $\begin{array}{c}\text { Dominant } \\
\text { Hand }\end{array}$ & $\begin{array}{c}\text { Non } \\
\text { Dominant } \\
\text { Hand }\end{array}$ & \\
\hline & & & & $\begin{array}{l}\text { Shoulder } \\
\text { adduction }\end{array}$ & & & \\
\hline & & & & $\begin{array}{l}\text { Shoulder } \\
\text { Int. rot }\end{array}$ & & & \\
\hline & & & & $\begin{array}{c}\text { Elbow } \\
\text { extension }\end{array}$ & & & \\
\hline & \multirow{2}{*}{\multicolumn{2}{|c|}{$\begin{array}{l}\text { Release the } \\
\text { glass }\end{array}$}} & & $\begin{array}{c}\text { MP } \\
\text { extension }\end{array}$ & & & \\
\hline & & & & $\begin{array}{l}\text { Fingers } \\
\text { extension }\end{array}$ & & & \\
\hline \multirow{12}{*}{$\begin{array}{c}\text { Drawing a } \\
\text { line (right to } \\
\text { left) }\end{array}$} & \multirow{6}{*}{$\begin{array}{l}\text { Reach for the } \\
\text { paper on the } \\
\text { table }\end{array}$} & & & $\begin{array}{l}\text { Shoulder } \\
\text { flexion }\end{array}$ & & & \\
\hline & & & & $\begin{array}{c}\text { Elbow } \\
\text { extension }\end{array}$ & & & \\
\hline & & & & $\begin{array}{l}\text { Forearm } \\
\text { midposition }\end{array}$ & & & \\
\hline & & & & $\begin{array}{c}\text { Wrist } \\
\text { extension }\end{array}$ & & & \\
\hline & & & & $\begin{array}{c}\text { MP* } \\
\text { extension }\end{array}$ & & & \\
\hline & & & & $\begin{array}{l}\text { Fingers } \\
\text { extension }\end{array}$ & & & \\
\hline & \multirow{6}{*}{$\begin{array}{l}\text { Grip the } \\
\text { pen/pencil } \\
\text { (dynamic } \\
\text { tripod) }\end{array}$} & & & $\begin{array}{l}\text { Forearm } \\
\text { pronation }\end{array}$ & & & \\
\hline & & & & $\begin{array}{l}\text { MP slight } \\
\text { flexion }\end{array}$ & & & \\
\hline & & & & $\begin{array}{l}\text { Fingers } \\
\text { slight } \\
\text { flexion }\end{array}$ & & & \\
\hline & & & & $\begin{array}{c}\text { Thumb } \\
\text { opposition } \\
\text { with } 2 \& 3 \\
\text { fingers }\end{array}$ & & & \\
\hline & & & & $\begin{array}{c}\mathrm{MCP}^{* *} \\
\text { slight } \\
\text { flexion }\end{array}$ & & & \\
\hline & & & & $\begin{array}{l}\text { Thumb } \\
\text { IP*** slight } \\
\text { flexion }\end{array}$ & & & \\
\hline
\end{tabular}




\begin{tabular}{|c|c|c|c|c|c|c|c|}
\hline \multirow{5}{*}{ Performance } & \multirow{3}{*}{ Whole task } & \multicolumn{2}{|c|}{ Scoring $0 / 1 / 2$} & \multirow[b]{2}{*}{ Part task } & \multicolumn{2}{|c|}{ Scoring $0 / 1 / 2$} & \multirow[b]{2}{*}{ Comments } \\
\hline & & $\begin{array}{c}\text { Dominant } \\
\text { Hand }\end{array}$ & $\begin{array}{c}\text { Non } \\
\text { Dominant } \\
\text { Hand }\end{array}$ & & $\begin{array}{c}\text { Dominant } \\
\text { Hand }\end{array}$ & $\begin{array}{c}\text { Non } \\
\text { Dominant } \\
\text { Hand }\end{array}$ & \\
\hline & & & & $\begin{array}{c}\text { Thumb } \\
\text { palmar } \\
\text { abduction }\end{array}$ & & & \\
\hline & $\begin{array}{l}\text { Connecting } \\
\text { the two }\end{array}$ & & & $\begin{array}{l}\text { Shoulder } \\
\text { adduction }\end{array}$ & & & \\
\hline & $\begin{array}{l}\text { points } \\
\text { together(right } \\
\text { to left) }\end{array}$ & & & $\begin{array}{l}\text { Shoulder } \\
\text { Int.rot }\end{array}$ & & & \\
\hline
\end{tabular}

*MP: Metacarpo-Phalangeal. **MCP: MetaCarpoPhalangeal. ***IP: Interphalangeal. 